\title{
Strategies and Applications of Antigen-Binding Fragment (Fab) Production in Escherichia coli
}

\author{
Hui Chen ${ }^{1 \#}$ Jun-Sheng Chen ${ }^{1 \#}$ Pameila Paerhati ${ }^{1}$ Tanja Jakos ${ }^{1}$ Si-Yi Bai ${ }^{1}$ Jian-Wei Zhu ${ }^{1}$ \\ Yun-Sheng Yuan ${ }^{1 *}$
}

${ }^{1}$ Engineering Research Center of Cell \& Therapeutic Antibody,
Shanghai Jiao Tong University College of Pharmacy, Ministry of
Education, Shanghai, People's Republic of China

Pharmaceut Fronts 2021;3:e39-e49.

\author{
Address for correspondence Yun-Sheng Yuan, PhD, Engineering \\ Research Center of Cell \& Therapeutic Antibody, Shanghai Jiao Tong \\ University College of Pharmacy, Ministry of Education, 800 \\ Dongchuan Road, Shanghai 200240, People's Republic of China \\ (e-mail: yunsheng@sjtu.edu.cn).
}

\begin{abstract}
Keywords

- mAbs

- Fab

- E. coli expression systems

- applications

With the advancement of genetic engineering, monoclonal antibodies (mAbs) have made far-reaching progress in the treatment of various human diseases. However, due to the high cost of production, the increasing demands for antibody-based therapies have not been fully met. Currently, mAb-derived alternatives, such as antigen-binding fragments (Fab), single-chain variable fragments, bispecifics, nanobodies, and conjugated mAbs have emerged as promising new therapeutic modalities. They can be readily prepared in bacterial systems with well-established fermentation technology and ease of manipulation, leading to the reduction of overall cost. This review aims to shed light on the strategies to improve the expression, purification, and yield of Fab fragments in Escherichia coli expression systems, as well as current advances in the applications of Fab fragments.
\end{abstract}

\section{Introduction}

Since the first therapeutic monoclonal antibody (mAb) drug was approved by the Food and Drug Administration (FDA), the past 30 years had witnessed substantial strides in the development of antibody therapeutics. During this period, more than $80 \mathrm{mAb}$ therapeutics have been approved for the market with the advances in technology. ${ }^{1}$ Among the marketed antibodies, the majority are fully human or humanized immunoglobulins (Igs), followed by a small fraction of antibody fragment-based therapeutics. Notably, full-length antibodies have a long circulating half-life, which makes them unsuitable for some diagnostic and therapeutic applications. $^{2}$ With the conjugation of some anticancer products to the effector molecules (such as radiolabels, chemicals, or toxins), antibody-drug conjugates (ADCs) are expected to expand into fields other than malignant tumors and autoim-

\# These authors contributed equally to this work.

received

May 27, 2021

accepted

July 3,2021
DOI https://doi.org/

$10.1055 / \mathrm{s}-0041-1735145$ ISSN 2628-5088. mune diseases, and will dominate the field of drug discovery in the near future. ${ }^{3}$ However, the growing needs of the market require pure molecules in large amounts, which is challenging to the production cost, the productivity of expression systems, as well as the quality of expressed recombinant antibody fragments.

To overcome the present problems, engineering of antibody-based fragments has represented a new direction to produce $\mathrm{mAb}$ alternatives with functional properties of conventional antibodies, for example, antigen-binding fragment (Fab), Fab dimers, single-chain variable fragments (scFvs), diabody (VHH), and ScFab (single-chain Fab) (-Fig. 1). ${ }^{4}$ As shown in -Fig. 1, IgG molecule $(\sim 150 \mathrm{kDa})$ is composed of two identical heavy chains ( $\sim 50 \mathrm{kDa})$ and two identical light chains ( $\sim 50 \mathrm{kDa})$. Fab is a fragment of Ig molecule with a heavy chain shortened by constant domains $\mathrm{CH} 2$ and $\mathrm{CH} 3$ while the Fab of heavy chain is called $\mathrm{VHH}$ antibody (or nanobody) ${ }^{5,6}$; scFvs are fragments of variable regions of the heavy and light chains, which are connected by

(c) 2021. The Author(s).

This is an open access article published by Thieme under the terms of the Creative Commons Attribution License, permitting unrestricted use, distribution, and reproduction so long as the original work is properly cited. (https://creativecommons.org/licenses/by/4.0/)

Georg Thieme Verlag KG, Rüdigerstraße 14, 70469 Stuttgart,

Germany 

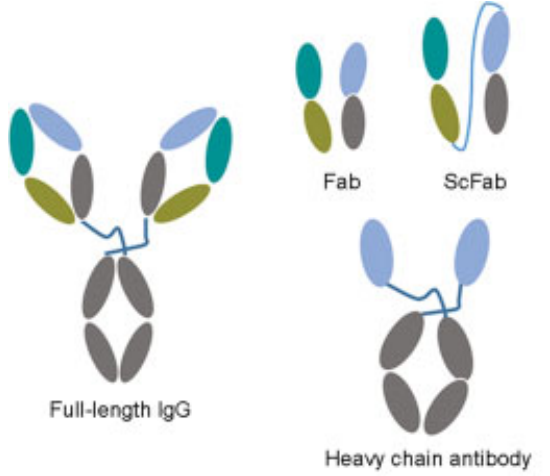
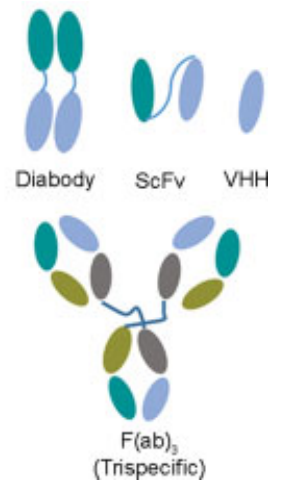

Fig. 1 The structure of $\mathrm{ggG}$ and $m A b$-derived alternatives. $\mathrm{Ig} G$, immunoglobulin $\mathrm{G}$; mAb, monoclonal antibody.

a peptide linker ${ }^{7}$; ScFab is the fragment in which the carboxy-terminus of the constant light chain is fused to the amino-terminus of the variable heavy chain via a flexible linker. ${ }^{8}$ Among those alternatives, Fab would be the most suitable fragment for clinical applications, and the reasons may be attributed to the following aspects: (1) Fab fragments have better tissue penetration capacity and faster clearance than the larger intact mAbs, and thus may represent a better way to selectively deliver radioisotopes, toxic drugs, and toxins to the target site; (2) Fab fragments lack Fc domain, which renders them the ability to bind antigen monovalently without mediating antibody effector functions and reducing immunogenicity; and (3) Fab is more stable than ScFv and can be expressed in Escherichia coli, which has been recognized as being easier production, lower costs, as well as compatibility with phage display. ${ }^{9}$

Fab was generated by enzyme digestion. ${ }^{5}$ Papain and aspartic acid protease pepsin are two enzymes that are frequently used to digest IgG1 to produce the majority of Fab, as well as $\mathrm{F}\left(\mathrm{ab}^{\prime}\right)_{2}$ fragments, respectively. IgG-degrading enzymes Streptococcus pyogenes (IdeS protease) and endoproteinase Lys- $\mathrm{C}$ are shown to be attractive alternatives to generate $F\left(a b^{\prime}\right)_{2}$ and Fab fragments with better fragment yields and less nonspecific cleavage. ${ }^{10}$ However, enzyme digestion was usually accompanied with inefficient proteolysis that is hard to control, and the production of heterogeneous Fab cannot be genetically manipulated. ${ }^{11}$ Considering this, current efforts are focusing on the directed generation of Fab fragments as recombinant proteins that can be expressed in a wide range of expression systems such as bacteria, ${ }^{12}$ yeast, ${ }^{13}$ insects, ${ }^{14}$ and mammalian cells. ${ }^{15}$ An E. coli expression system has various advantages over other systems including its low cost, rapid growth on inexpensive substrates, high biomass, readily scalable cultivation, and easy genetic manipulation for therapeutic protein production. ${ }^{16}$

However, the expression level of Fab fragments in E. coli is low. Fab fragments contain disulfide bonds (four intrachain and one interchain) required for structural and functional integrity. Incorrectly folded Fab fragments can inevitably be generated. ${ }^{5}$ Apart from incorrect folding, low expression levels of Fab fragments in $E$. coli can be ascribed to toxicity effects, intracellular degradation, aggregation, and inefficient translocation. According to the literature, the typical yield of Fab proteins in E. coli flask cultures ranges from 0.1 to $10 \mathrm{mg} / \mathrm{L}$ and high-density E. coli cultures grown in laboratory fermenters can yield up to $1 \mathrm{~g} / \mathrm{L} .{ }^{17}$ In most cases, the Fab expression yield can be further optimized from undetectable level to a relatively high yield through genetic engineering.

In this review, we discuss several factors, such as different vector elements, bacterial strains, and cultivation conditions, to mitigate potential problems, and explore the influence of gene sequence, secretion signal sequences, and chaperone co-expressions on expression yields of Fab fragments. Furthermore, the development and the prospects of Fab fragments are examined in detail.

\section{Expression of Fab Fragment in E. coli}

The cytoplasm of $E$. coil is a reducing environment maintained by the thioredoxin-thioredoxin reductase (trxB) system and the glutaredoxin-glutaredoxin reductase (gor) system. ${ }^{18}$ In fact, the formation of disulfide bond rarely occurs in the cytoplasm. Cysteine residues are part of catalytic sites in many enzymes, where the formation of disulfide bond could lead to protein inactivation, misfolding, and aggregation. ${ }^{19}$ However, the formation of disulfide bond can be specifically achieved in prokaryotic periplasm and eukaryotic endoplasmic reticulum, during which proteins need to be directed to these compartments with the help of signal peptides or leader peptides. ${ }^{16}$ When the gene $(\operatorname{tr} x B)$ is inactivated by mutation, and structural disulfide bonds within a protein is then formed in the cytoplasm, followed by the possible production of Fab fragments in the cytoplasm. Thus, Fab fragments can be expressed in the cytoplasm of E. coli, either as soluble proteins or inclusion bodies (IBs), and can also be secreted to the periplasm or to the culture medium through signal peptides. The expression of Fab fragment in E. coli is cost-effective, and through various optimization methods, the expression, solubility, and stability of Fab fragment can be improved within a short time.

\section{Expression of Fab in the Cytoplasm}

Whether a product remains soluble or as aggregates in the cytoplasm depends on intrinsic properties of the peptide or protein sequence, promoter strength, and fermentation parameters, such as temperature and growth rate. ${ }^{20}$ When proteins are expressed at high levels in E. coli, it is common to find that most of the proteins are insoluble, which called IBs. ${ }^{21}$ A possible explanation for the formation of IB is the lack of required cell machinery and overexpression of heterologous proteins in the cytoplasm when a protein is partially folded or misfolded. ${ }^{22}$

To enhance the production of soluble functional antibody Fab fragments in an oxidizing bacterial cytoplasm, different methods have been described. For instance, Venturi et al reported an approach of utilizing redox-mutant strains with increased oxidizing capacity to permit the correct folding of Fab fragments. ${ }^{11}$ When an oxidizing cytoplasmic environment was successfully provided by thioredoxin- and glutathione reductase-deficient $E$. coli strain FA113, the expression of (soluble) Fab will be increased by 50- to 250- 
fold in comparison to other reported overexpression strategies. Some other approaches include co-expression of different folding enzymes, such as peptidyl-prolyl cis/transisomerases and periplasmic dithiol-disulfide oxidoreductases. ${ }^{23}$ Gaciarz et al also suggested a system called CyDisCo used for efficient production of disulfide bond containing proteins in the cytoplasm of E. coli. ${ }^{16}$ CyDisCo is based on coexpression of a sulfhydryl oxidase and a protein disulfide isomerase, which catalyze the formation and isomerization of the disulfide bond. The results indicated that more than $90 \%$ of the tested scFv and Fab fragments could be produced and correctly folded in the biologically active form within the cytoplasm. ${ }^{16}$ Furthermore, the addition of certain fusion partners, such as maltose-binding protein and small ubiquitin-related modifier (SUMO), is also reported to improve stability, solubility, and the expression yield of recombinant proteins. ${ }^{16}$ In 2017, Rezaie et al applied a dual SUMO fusion strategy to successfully obtain a Fab fragment with correct folding $(12 \mathrm{mg} / \mathrm{L}) .{ }^{24}$ Moreover, the fusion of leucine zipper (LZ) pairs LZA and LZB or C-Jun and C-Fos to the C-terminus of heavy and light chains, respectively, enhanced correct pairing of the heavy and light chains that led to the production of active Fab as Zipbody in the E. coli expression system. ${ }^{25}$

However, Fab fragments are more commonly expressed as IBs in the cytoplasm of $E$. coli. Although protein expression in the form of IBs is often undesirable, their formation is advantageous because of the high purity of the target protein in the aggregate fraction and the increased protection from proteolytic degradation when compared with the soluble counterpart. $^{26,27}$ IBs should be isolated and solubilized, followed by refolding and purification of solubilized proteins to achieve functional activity. Among these steps, solubilization and refolding are the crucial processes for high recovery. IBs can be traditionally solubilized using high concentrations of denaturants like urea and guanidine hydrochloride
$(\mathrm{GdnHCl}),{ }^{28}$ or with the advanced methods employing detergents, organic solvents, and low concentrations of chaotropes. ${ }^{29}$ Refolding is identified as formation of disulfide bonds in the presence of optimal concentrations of both oxidizing and reducing agents, and usually performed using pairs of redox agents, such as reduced/oxidized glutathione (GSH/GSSG), DTT/GSSG, cysteine/cystine, and cysteamine/ cystamine with a molar ratio of reduced to oxidized compounds of $1: 1$ to $10: 1 .^{30}$ Furthermore, the optimal conditions of refolding can be acquired by the addition of additives to buffers to reduce protein aggregation and misfolding. The most commonly used additives with low molecular weights are $L$-arginine, low-concentration (1-2 mol/L) urea, and detergents. ${ }^{31}$ Buchner and Rudolph designed a renaturation procedure that allowed the production of microbially expressed Fab fragments at the yields up to $40 \%$ of the total amount of recombinant protein, by which the obtained recombinant Fabs were identical to the parental murine Fab in functional and physicochemical parameters. ${ }^{32}$ IBs offer an attractive manufacturing option. Currently, there are two marketed Fab fragments, which are expressed as IBs in the cytoplasm of E. coli: ranibizumab (Lucentis) and certolizumab pegol (Cimzia).

\section{Expression of Fab in the Periplasm}

It is clear that extracellular protein expression is preferred over conventional cytoplasmic expression with a simpler downstream purification process and more efficient protein folding. ${ }^{33}$ Unfortunately, the yields of Fab fragments in periplasm are often relatively low, because of hurdles like inefficient translocation across the inner membrane, protein folding, proteolysis, and toxicity. ${ }^{34}$-Fig. 2 depicts some factors that may help solve the problem as mentioned, and the corresponding approaches may include optimization of secretion signal sequences; co-expression of molecular
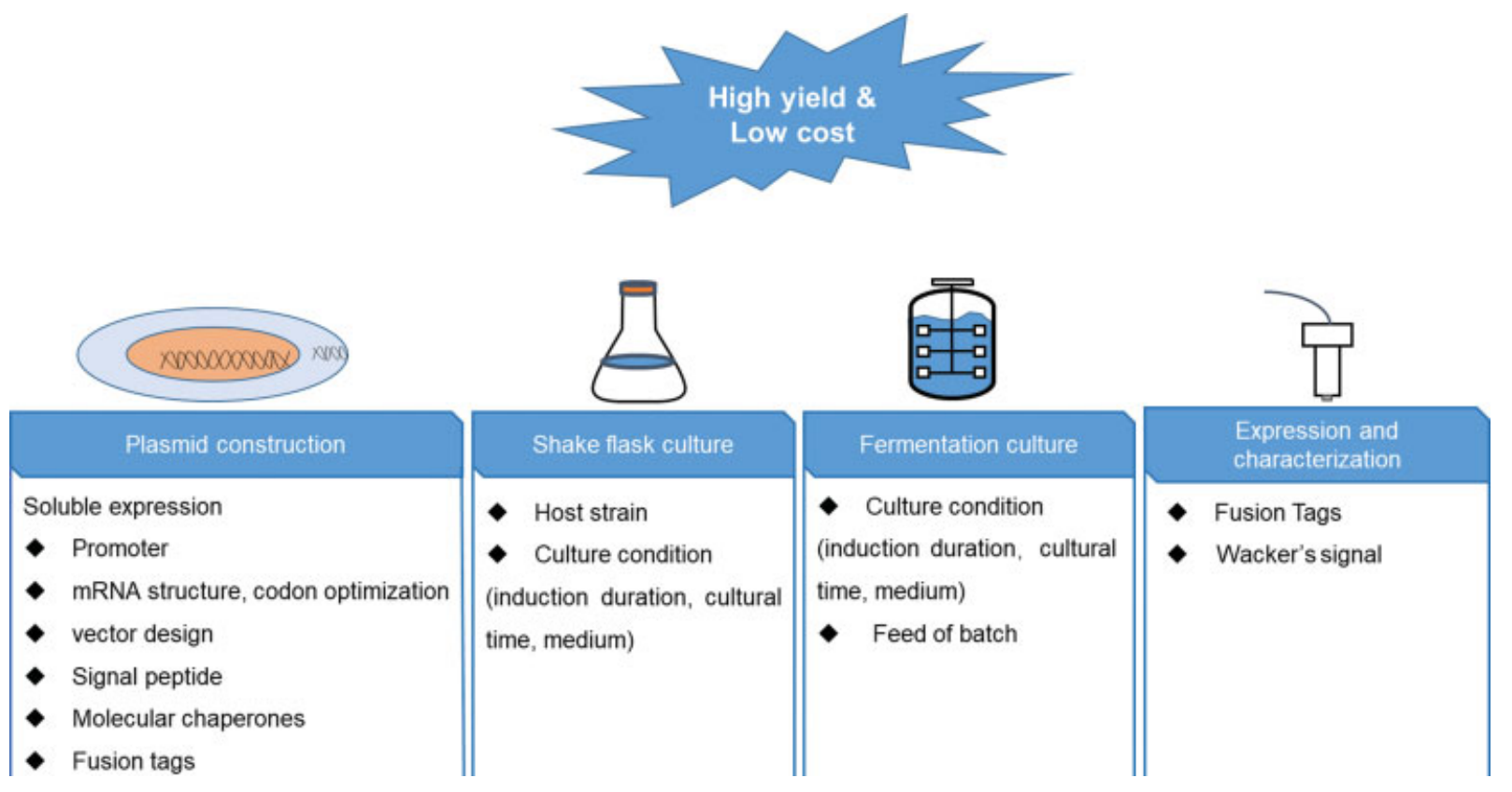

Fig. 2 A proposed technology in E. coli to generate cost-effective Fab fragment. 
chaperones for proper disulfide bridging; host bacteria mutants; and incorporation of expression augmenting genetic elements into the vector. ${ }^{35}$ Toxicity of some Fab fragments can be greatly reduced by modulating transcriptional and translational rates, typically by inducing protein expression at low temperature, by modification of culture medium, ${ }^{36}$ or by using more tightly controlled promoters.

There is no general rule to optimize culture parameters. It should be evaluated on a case-by-case basis, since not all factors play an equally important role in improving the expression of a specific protein. For example, to boost bacterial expression, Lin et al combined several methods such as design of a new expression vector, optimization of Fab light-chain codons, and co-expression of chaperon protein, which eventually increased the production of Fab in $E$. coli by 100 -fold. ${ }^{37}$

\section{Signal Peptide}

The periplasm of $E$. coli is a redox environment enriched with foldases including disulfide isomerases (Dsb proteins) and peptidyl-prolyl isomerases, which facilitate correct disulfide bond formation of the proteins of interest. ${ }^{38}$ Routing to the periplasmic space is achieved by fusing the recombinant protein to a proper signal peptide. The translocation mechanism depends on the type of signal peptide. Escherichia coli secretary pathway (SEC) and the signal recognition particle (SRP)-dependent translocation machinery are responsible for transporting/targeting most of the proteins into the periplasm, while the TAT (twin-arginine translocation) pathway enables translocation of folded proteins only in E. coli mutants with oxidative cytoplasm. ${ }^{13}$ In addition, signal peptides play a crucial role in controlling secretion efficiency. Among the common leader peptides, four use the SEC pathway (PelB, OmpA, PhoA, and pIII) and three use the SRP pathway (DsbA, TorT, and TolB). In 2008, Thie et al compared SRP and SEC pathway leader peptides for antibody fragment production in $E$. coli and concluded that both pathways were compatible with antibody phage display and production of soluble antibody fragments. ${ }^{39}$ Additionally, Nagano et al revealed that alteration of the Ser to Ala at -3 and -1 in the C-region of the signal peptide could significantly improve the Fab secretion in E. coli. ${ }^{40}$ Their modified signal peptide could be applied to enhance periplasmic expression of antibody fragments in E. coli.

\section{Vector Engineering}

Vector design plays a key role for the successful expression of Fab in E. coli. ${ }^{36}$ Currently, three different vector cassettes are utilized to express Fab molecules in E. coli: (1) VL-CL and $\mathrm{VH}-\mathrm{CH} 1$ genes driven by two promoters in two separate expression cassettes ${ }^{41}$; (2) one dicistronic expression cassette with two translation initiation sites with $\mathrm{VH}-\mathrm{CH} 1$ before $\mathrm{VL}-\mathrm{CL}^{42}$; and (3) one dicistronic expression cassette with two translation initiation sites with VL-CL before VH$\mathrm{CH} 1{ }^{43}$ Corisdeo and Wang compared three expression cassettes to produce a human Fab against tetanus toxoid and showed that the third vector enabled the largest increase (eightfold) in the production levels of secreted and correctly assembled Fab. For basic research purposes, the second ( 2 ) design is predominant. ${ }^{36}$

\section{Codon Usage}

It is well known that codon usage plays a significant role in gene expression levels and protein folding. In the past decade, considerable progress in the speed and cost of gene synthesis facilitated the complete redesign of entire gene sequences, thus markedly improving the likelihood of successful production of heterologous proteins for academic as well as biopharmaceutical use. ${ }^{44}$ It is believed that codon usage alters protein folding and modulates the efficiency of translation initiation. ${ }^{45}$ Studies suggested that rare codons had a bigger effect on increasing protein expression than more common codons. ${ }^{46}$ Previous studies showed a striking abundance of nonoptimal codons in the signal sequences of secretory proteins. Accordingly, alteration of synonymous codon in the signal sequence also affects protein yield by slowing the rate of translation across the N-terminal signal sequence to facilitate proper folding of the secreted protein or by facilitating the binding to the SRP, consequently leading to more efficient translocation. ${ }^{47,48}$ Optimization of codon usage of signal sequences was successfully employed in improving the expression levels of antibody fragments. Kulmala et al established synonymous PelB signal sequence libraries attached to light and heavy chains of a Fab fragment, and discovered that codon usage of the fifth leucine position of the light-chain PelB affects the expression levels of Fab fragment. ${ }^{49}$

\section{Molecular Chaperones}

Co-expression of molecular chaperons can decrease accumulation of IBs and can assist proteins in adopting the correct conformation. These chaperons are foldases tailored to help trigger protein folding by interacting with the expressed proteins and form a protein-chaperon complex. ${ }^{50}$ It is well documented that co-expression with molecular chaperons improves solubility and proper folding of various recombinant proteins and antibody fragments. ${ }^{38}$ DnaK chaperones act in an ATP-dependent manner and cooperate with DnaJ and GrpE co-chaperones to mediate protein folding under both normal and stressful growth conditions. ${ }^{51}$ Dsb (disulfide bond) enzymes $A-G$ are found within the periplasm and are involved in the catalysis of disulfide bonds. ${ }^{34}$ DsbA typically catalyzes disulfide bond formation in folding proteins while DsbC functions as a disulfide isomerase. The coexistence of these two proteins as the thiol-disulfide oxidoreductases allows the establishment of disulfide bridges. The DsbA mutations could stabilize the $\alpha$-helical structure of the hydrophobic core and enhance binding to SRP, resulting in a higher expression. ${ }^{8}$ In addition to Dsb proteins, periplasmic peptidyl-prolyl isomerases FkpA and SurA are also involved in the protein-folding process. FkpA can alleviate the stress response in E. coli cells during accumulation of misfolded proteins, suppress the formation of IBs, and promote proper folding. ${ }^{52}$ In addition, SurA maintains outer membrane integrity and also catalyzes the folding of other outer membrane proteins. ${ }^{53}$ 


\section{Host Bacteria}

Humanized Fab fragments, produced in the periplasm of E. coli, are subject to degradation caused by host-cell proteases. To increase Fab yield and reduce proteolysis, E. coli strains deficient in periplasmic proteases, but still able to maintain high cell density, were developed. These strains lack the protease activity of Tsp, protease III, and DegP, and incorporate suppressor mutations in the spr gene to restore the wild-type phenotype of the cells, thereby increasing the productivity by twofold. ${ }^{34}$ E. coli BL21 (DE3) and K12 hosts are extensively used for the production of various forms of biopharmaceuticals. BL21 cells are deficient in the Lon protease, which degrades many foreign proteins. Several commercialized $\mathrm{K} 12$ host bacteria strains exist, such as $E$. coli W3110, Rosetta-gami 2, SHuffle T7, and MG1655, some of which carry additional modifications for improved folding. Rosetta-gami 2 contains $\operatorname{tr} x B$ and gor gene mutations. Shuffle T7 contains trxB and gor gene mutations as well as constitutive DsbC expression, and MG1655 generally shows a high growth rate and productivity. ${ }^{33}$ Escherichia coli strain FA113 also lacks the activity of thioredoxin and glutathione reductase, and its oxidizing cytoplasmic environment enabled Venturi et al to express two Fab fragments in the cytoplasm with very high yields at $10-30 \mathrm{mg} / \mathrm{L} .{ }^{11}$ Nonetheless, it is difficult to predict which kind of host bacteria would generate the best yields. Therefore, perhaps due to their well-documented use, E. coli W3110 and BL21(DE3) remain prevalent strains in the expression of Fab fragments.

\section{Culture Condition and Feed Batch}

Control of the growth temperature during fermentation allows the stable expression of heterologous proteins. ${ }^{54}$ Previous studies demonstrated that low-temperature fermentation (below $30^{\circ} \mathrm{C}$ ) is advantageous for Fab expression in $E$. coli on account of the reduced translation rate and protein aggregation. At low temperatures, the rate of synthesis of the target protein is slow and the rate of transport to the periplasm is correspondingly reduced, and subsequently reduces the burden on bacteria. The composition of the medium also has an important impact on soluble expression. Medium rich in metal and salt ions is more suitable to Fabsoluble expression. Metal ions assist in the formation of disulfide-bonded enzymes, and increase soluble expression. Evidence suggests that addition of $\mathrm{Mg}^{2+}$ to the medium can improve the soluble expression by $50 \%{ }^{55}$ For large-scale production, the optimization of fermentation conditions is crucial to improve yields. Kim et al reported that increased nitrogen supply together with low temperature significantly improved the yield of biologically active form of Fab by 59.7\%. ${ }^{56}$ An et al developed a fed-batch fermentation process using glycerol as a carbon source, which achieved soluble biologically active protein at $80 \mathrm{mg} / \mathrm{L} .{ }^{57}$ In - Table 1, we list studies that successfully achieved expression of Fab in E. coli.

\section{Leakage into the Extracellular Medium}

Fab fragments that are directed toward the periplasmic space could, depending on the growth conditions, preferentially localize to the culture growth medium. ${ }^{58}$ Bäcklund et al investigated the leakage of proteins from periplasm to the medium. ${ }^{59}$ They suggested that a higher feed rate will not lead to higher amounts of product in the periplasm, since there is a comparatively higher leakage. Therefore, it is necessary to determine the dependency of Fab leakage on cultivation conditions, a practical way to manipulate Fab localization. Ukkonen et al pointed out that the yield and leakage of Fab fragments are dependent on combination of several variables, including expression strain, culture medium, and aeration rate. Studies of the association between the temperature and aeration showed that low temperature $\left(30^{\circ}\right.$ C) decreased the leakage to the culture supernatant from 70 to $40 \%{ }^{60}$

Moreover, a promoter engineering strategy was also applied to reduce Fab' fragment leakage. Schofield et al reduced Fab' leakage by converting the promoter from Ptac to Ptic using site-directed mutagenesis. ${ }^{61}$ Balancing promoter strength with the overall metabolic burden of cellular "housekeeping" processes could also address translocon overload, caused by periplasmic translocation of exogenous proteins. Wacker's ESETEC secretion technology was an efficient technology for the expression and secretion of Fab exceeding $4.0 \mathrm{~g} / \mathrm{L}$, which was approximately 40-fold higher than secretion into the periplasm. ${ }^{35}$ Wacker's ESETEC platform contained two steps: briefly, the recombinant product was first translocated into the periplasmic space via the Sec pathway of $E$. coli, where it folded in a correct conformation, and then it was selectively transported across the outer membrane into the fermentation broth.

Fab-based fusion proteins, such as immunocytokines and immunotoxins, have also been studied. Fab and fusion protein are either expressed separately and then connected by a linker, or the Fab and protein are genetically fused together as a whole molecule. ${ }^{62}$ Holzer et al expressed Fab IL-8 (CXCL8 ) fusion protein in the periplasm of $E$. coli with the aid of the pel B leader sequence, which showed specific binding to IL-8 receptors and also displayed chemotactic activity. ${ }^{63}$ Moreover, Nelke et al fused a single-chain-encoded B cell activating factor (scBaff) trimer to Fab against TNFRSF members, and proved that the fusion proteins remained intact in the antibody-scBaff fusion proteins. ${ }^{64}$ Bauss et al developed RG7787, a humanized SS1 Fab fragment fused with 24-kD fragment of Pseudomonas exotoxin A (PE24), with inhibitory effect on proliferation of lung cancer cell lines with picomolar potency both in vitro and in vivo. ${ }^{65}$

\section{Purification of Fab Fragments Expressed in $E$. coli}

Fab fragments are classically generated by digesting immunoglobulin with papain, and purified by protein L affinity chromatography with a strong affinity to the variable region of kappa Lc of IgG molecule. ${ }^{61}$ However, its applicability is limited to the kappa light-chain Fab subclass. Furthermore, protein $\mathrm{L}$ requires extreme $\mathrm{pH}$ for elution and its performance is often not comparable with protein $A$ in the binding affinity, selectivity, and capacity. ${ }^{66}$ Also, several other chromatographic techniques, including antigen affinity, ion- 
Table 1 Summary of studies that report expression of Fab in E. coli, including the parameters that were critical for achieving the documented yield

\begin{tabular}{|c|c|c|c|c|c|c|}
\hline Parameter & Target & Vector & E. coli strain & Condition & Yield & Reference \\
\hline \multicolumn{7}{|l|}{ Promoter } \\
\hline $\mathrm{T7}$ & $\begin{array}{l}\text { Thrombopoietin } \\
\text { mimic }\end{array}$ & pET28a modified & Not mentioned & $\begin{array}{l}22^{\circ} \mathrm{C}, 16-20 \mathrm{~h}, \\
0.02 \mathrm{mmol} / \mathrm{L} \text { IPTG }\end{array}$ & $3.5 \mathrm{mg} / \mathrm{L}$ & 37 \\
\hline Ptic & Not mentioned & $\begin{array}{l}\text { pTTODA33 } \\
\text { modified }\end{array}$ & E. coli W3110 & $\begin{array}{l}\text { Fed-batch } \\
\text { fermentation }\end{array}$ & Not mentioned & 61 \\
\hline phoA & VEGF-A & pBR322 vector & E. coli W3110 & $\begin{array}{l}\text { Fed-batch } \\
\text { fermentation }\end{array}$ & $332 \mathrm{mg} / \mathrm{L}$ & 56 \\
\hline Arabinose & $\begin{array}{l}\text { Matrix } \\
\text { metalloproteinase- } \\
14\end{array}$ & Self-constructed & BL21 & $\begin{array}{l}30^{\circ} \mathrm{C} \text {, overnight, } \\
0.2 \% \text { arabinose }(w / v)\end{array}$ & Not mentioned & 90 \\
\hline \multicolumn{7}{|l|}{ Signal peptide } \\
\hline STII & VEGF-A & pBR322 vector & E. coli W3110 & $\begin{array}{l}\text { Fed-batch } \\
\text { fermentation }\end{array}$ & $332 \mathrm{mg} / \mathrm{L}$ & 56 \\
\hline PelB & HER2 & $\begin{array}{l}\text { pFLAG-based } \\
\text { vector }\end{array}$ & E. coli W3110 & $\begin{array}{l}20^{\circ} \mathrm{C} \text {, overnight, } \\
0.1 \mathrm{mmol} / \mathrm{L} \text { IPTG }\end{array}$ & Not mentioned & 40 \\
\hline OmpA & HER2 & $\begin{array}{l}\text { pFLAG-based } \\
\text { vector }\end{array}$ & E. coli W3110 & $\begin{array}{l}20^{\circ} \mathrm{C} \text {, overnight, } \\
0.1 \mathrm{mmol} / \mathrm{L} \text { IPTG }\end{array}$ & Not mentioned & 40 \\
\hline \multicolumn{7}{|l|}{ Chaperone } \\
\hline CyDisCo & HER2 & pET23 modified & $\begin{array}{l}\text { K12 E. coli } \\
\text { modified }\end{array}$ & $\begin{array}{l}30^{\circ} \mathrm{C}, 6 \mathrm{~h}, \\
0.5 \mathrm{mmol} / \mathrm{L} \mathrm{IPTG}\end{array}$ & $3-50 \mathrm{mg} / \mathrm{mL}$ & 16 \\
\hline DsbC & Not mentioned & pKO3 modified & W3110 mutated & $\begin{array}{l}30^{\circ} \mathrm{C} \text {, overnight, } \\
200 \mu \mathrm{mol} / \mathrm{L} \text { IPTG }\end{array}$ & $2.4 \mathrm{~g} / \mathrm{L}$ & 34 \\
\hline DsbA & Not mentioned & pET30a & BL21 (DE3) & $\begin{array}{l}\text { Fed-batch } \\
\text { fermentation }\end{array}$ & $\begin{array}{l}0-7.4 \mathrm{~g} / \mathrm{g} \\
\text { (cell dry mass) }\end{array}$ & 91 \\
\hline Skp & Digoxin & pET25b & Origami (DE3) & $\begin{array}{l}30^{\circ} \mathrm{C}, 3 \mathrm{~h}, \\
1 \mathrm{mmol} / \mathrm{L} \text { IPTG }\end{array}$ & $0.8 \mathrm{mg} / \mathrm{L}$ & 42 \\
\hline $\begin{array}{l}\text { DnaK/Dnaj/ } \\
\text { GrpE }\end{array}$ & TNF- $\alpha$ & $\begin{array}{l}\text { pET-22b } \\
\text { modified }\end{array}$ & Shuffle & $\begin{array}{l}25^{\circ} \mathrm{C}, 8 \mathrm{~h}, \\
0.1 \mathrm{mmol} / \mathrm{L} \mathrm{IPTG}\end{array}$ & $0.98 \mu \mathrm{g} / \mathrm{mL}$ & 92 \\
\hline \multicolumn{7}{|l|}{ Fusion tags } \\
\hline SUMO & VEGF & pET28 modified & Shuffle & $\begin{array}{l}30^{\circ} \mathrm{C}, 6 \mathrm{~h}, \\
0.5 \mathrm{mmol} / \mathrm{L} \mathrm{IPTC}\end{array}$ & $12 \mathrm{mg} / \mathrm{L}$ & 24 \\
\hline $\begin{array}{l}\text { Leucine } \\
\text { zipper-peptide }\end{array}$ & E. coli 0157 & pET22b & Shuffle & $\begin{array}{l}16^{\circ} \mathrm{C}, 24 \mathrm{~h}, \\
1 \mathrm{mmol} / \mathrm{L} \text { IPTG }\end{array}$ & $2.5 \mathrm{mg} / \mathrm{mL}$ & 25 \\
\hline \multicolumn{7}{|l|}{ Medium } \\
\hline Enbase & VEGF & pET28 modified & Shuffle & $\begin{array}{l}30^{\circ} \mathrm{C}, 6 \mathrm{~h}, \\
0.5 \mathrm{mmol} / \mathrm{L} \mathrm{IPTG}\end{array}$ & $12 \mathrm{mg} / \mathrm{L}$ & 24 \\
\hline $\begin{array}{l}\text { Luria-Bertani } \\
\text { medium }\end{array}$ & EBOLA virus & pD444-SR & $\begin{array}{l}\text { BL21 (DE3) } \\
\text { pLysS strain }\end{array}$ & $\begin{array}{l}30^{\circ} \mathrm{C} \text {, overnight, } \\
1 \mathrm{mmol} / \mathrm{L} \text { IPTG }\end{array}$ & $5-10 \mathrm{mg} / \mathrm{L}$ & 93 \\
\hline
\end{tabular}

Abbreviations: IPTG, Isopropyl B-D-1-thiogalactopyranoside; SUMO, small ubiquitin-related modifier; TNF, tumor necrosis factor; VEGF, vascular endothelial growth factor.

exchange, size-exclusion chromatography, and hydrophobic interaction, have been adopted for the purification of Fab fragments. ${ }^{67}$

Affinity-based chromatography is the most widely applied technique to purify Fab fragments. Affinity chromatography can separate antibodies on the basis of their specific and reversible interaction with immobilized target antigens or tags. ${ }^{68}$ There are four main steps in affinity-based purification, including equilibration, binding, washing, and elution. At present, immobilized metal affinity chromatography offers a series of advantages over other affinity ligands, such as ligand stability, low cost, high loading capacity, mild elution conditions, and easy regeneration in large-scale purification. The separation mechanism could be roughly described as the following: initially, the recombinant antibodies with specific group tags (e.g., histidine tag) are bound onto the resin, then nontagged proteins and most impurities are washed away, and finally the protein of interest is eluted by changing the $\mathrm{pH}$ or by addition of a competitive molecule. $^{4,69}$

Some novel affinity-based chromatography strategies are applied for antibody purification. Alves et al described an 
affinity chromatography method that utilized unconventional nucleotide-binding site (NBS) present on the antibody Fab arms as a target for selective purification of antibodies from complex mixtures. ${ }^{70}$ The affinity column was prepared by coupling indole butyric acid, which had a monovalent affinity for the NBS, and could consistently yield $>95 \%$ antibody recovery with $>98 \%$ purity during purifications performed with the chimeric mAb rituximab. Spooner et al tested the ability of a novel anti-CH1 resin, CaptureSelect IgG-CH1, which can effectively purify correctly assembled Fab and remove the light-chain dimer as a generic one-step process for both kappa and lambda type Fab. ${ }^{71}$ In addition, ion exchange chromatography is a technique used for purification of charged biomolecules on the basis of reversible interactions between oppositely charged biomolecules and chromatography resins, ${ }^{72}$ and based on the great capacity of cation exchangers for the capturing and concentrating target proteins in the early stage of purification process, the ionexchange chromatography method has also been used for the purification of the fragment. ${ }^{73,74}$ Typically, a combination of multiple chromatographic steps is needed when designing the optimal purification strategies of industrially manufactured Fab.

\section{Application of Fab Fragment}

Among the seven marketed Fab fragment drugs, only ranibizumab and certolizumab pegol are generated in E. coli as IBs, and the remaining Fabs are produced by cleavage of IgG with papain. - Table 2 lists the monoclonal Fab antibody fragments approved by FDA. Ranibizumab is a recombinant, humanized, affinity-matured, mAb Fab fragment against all isoforms of vascular endothelial growth factor-A (VEGF-A), which was developed specifically for intraocular use. ${ }^{75} \mathrm{Nu}-$ merous randomized and controlled clinical trials showed that this medication was effective in improving both vision and anatomical outcomes. Because Fab fragments had considerably shorter serum half-life than full-length antibodies, and Nakamura et al suggested a strategy to prolonging circulating half-life by conjugation of polyethylene glycol (PEG) to Fab. ${ }^{76}$ Certolizumab pegol is a PEGylated Fab fragment of anti-tumor necrosis factor- $\alpha$ for the treatment of psoriasis, Crohn's disease, and rheumatoid arthritis. ${ }^{77-79}$ - Table 2 shows the Fab fragments approved by FDA and $\boldsymbol{\sim}$ Table 3 lists some monoclonal Fab antibody fragments that are being studied in clinics.

Conjugating with a functional molecule including fluorophore, enzyme, toxin, or drug represents a promising strategy to achieving additional functionalities of antibody fragments, such as serving as detecting agents or $\mathrm{ADC}^{80}$ ADCs are composed of a targeting moiety represented by a $\mathrm{mAb}$ or antibody fragment and a cytotoxic compound that is either chemically conjugated or genetically fused. Due to a better distribution or penetration in vivo as well as reduced immunogenicity, the ADC may lead to increased therapeutic effects. ${ }^{81}$ To enhance killing activity of gelonin on cancer cells, Kornberger and Skerra designed a novel antibody-toxin conjugate, Fab-gelonin, in which anti-HER2 Fab was fused with the extended SrtA recognition motif at the C-terminus of its heavy chain to prevent interference with antigen binding, while the toxin was fused through a Gly $\mathrm{G}_{2}$ sequence at its N-terminus. ${ }^{82}$ Huang et al applied bis(vinylsulfonyl) piperazines as efficient linkers to selectively re-bridge disulfides of the Fab regions and produced highly homogeneous conjugates loaded with two drugs, with superior efficacy and reduced toxicity in comparison to the FDA-approved drug: Trastuzumab emtansine (also known as T-DM1). ${ }^{83}$ Wissler et al illustrated the utility of site-specific Fab conjugation as a general strategy for making sensitive positron emission tomography imaging probes, which allowed for effective

Table 2 Monoclonal Fab antibody fragments approved by FDA

\begin{tabular}{|l|l|l|l|l|l|}
\hline $\begin{array}{l}\text { Fab generic name } \\
\text { (brand name) }\end{array}$ & Description & Preparation & Indication & $\begin{array}{l}\text { Company } \\
\text { approval }\end{array}$ \\
\hline $\begin{array}{l}\text { Abciximab } \\
\text { (ReoPro) }\end{array}$ & $\begin{array}{l}\text { Anti-integrins } \alpha \text { II } \beta_{3} \\
\text { chimeric Fab }\end{array}$ & Papain & $\begin{array}{l}\text { Prevention: } \\
\text { restenosis }\end{array}$ & Centocor, Inc. & 1994 \\
\hline $\begin{array}{l}\text { Arcitumomab } \\
\text { (CEA-Scan) }\end{array}$ & $\begin{array}{l}\text { Fab' labeled with 99mTc } \\
\text { against CEA }\end{array}$ & Papain & $\begin{array}{l}\text { Diagnosis: } \\
\text { colon cancer }\end{array}$ & N/A & 1996 \\
\hline $\begin{array}{l}\text { Crotalidae } \\
\text { Polyvalent Immune Fab } \\
\text { (CroFab) }\end{array}$ & Polyclonal sheep Fab & Papain & $\begin{array}{l}\text { Therapy: } \\
\text { snake bites }\end{array}$ & 2000 \\
\hline $\begin{array}{l}\text { Digoxin Immune } \\
\text { Fab (DigFab) }\end{array}$ & Polyclonal sheep Fab & Papain & $\begin{array}{l}\text { Therapy: } \\
\text { Digoxin overdose }\end{array}$ & N/A \\
\hline $\begin{array}{l}\text { Ranibizumab } \\
\text { (Lucentis) }\end{array}$ & Anti-VEGF-A humanized Fab & E. coli & $\begin{array}{l}\text { Therapy: } \\
\text { macular degeneration }\end{array}$ & Genentech & 2006 \\
\hline $\begin{array}{l}\text { Certolizumab pegol } \\
\text { (Cimzia) }\end{array}$ & Anti-TNF- $\alpha$ PEGylated & E. coli & $\begin{array}{l}\text { Therapy: } \\
\text { Crohn's disease }\end{array}$ & UCB, Inc. & 2008 \\
\hline $\begin{array}{l}\text { Idarucizumab } \\
\text { (Praxbind) }\end{array}$ & Anticoagulant, humanized Fab & Papain & $\begin{array}{l}\text { Therapy: } \\
\text { antidote to dabigatran } \\
\text { etexilate (Pradaxa) }\end{array}$ & $\begin{array}{l}\text { Boehringer } \\
\text { Ingelheim }\end{array}$ & 2015 \\
\hline
\end{tabular}

Abbreviation: CEA, carcinoembryonic antigen. 
Table 3 Monoclonal Fab antibody fragments studied in clinic (Sources: clinicaltrials.gov, drugbank)

\begin{tabular}{|l|l|l|l|}
\hline $\begin{array}{l}\text { Fab generic name } \\
\text { (brand name) }\end{array}$ & Description & Clinical Indication & $\begin{array}{l}\text { Development status } \\
\text { (NCT number) }\end{array}$ \\
\hline Certolizumab pegol & Anti-TNF- $\alpha$ PEGylated humanized Fab & Juvenile idiopathicarthritis & Phase III [NCT01550003] \\
\cline { 3 - 4 } & & Interstitial cystitis & Phase III [NCT01550003] \\
\hline $\begin{array}{l}\text { Abciximab } \\
\text { (ReoPro) }\end{array}$ & Anti-integrins $\alpha$ II $\beta_{3}$ chimeric Fab & Acute myocardialinfarction & Phase III [NCT00299377] \\
\cline { 2 - 4 } & $\begin{array}{l}\text { Acute coronary syndrome } \\
\text { (ACS) }\end{array}$ & Phase IV [NCT00133003] \\
\hline Abrezekimab & Anti-human-IL-13 humanized Fab & Asthma & Phase I [NCT02473939] \\
\hline Dapirolizumab pegol & Anti-CD40L PEGylated humanized Fab & $\begin{array}{l}\text { Systemic lupus } \\
\text { erythematosus }\end{array}$ & Phase II [NCT02804763] \\
\hline Glenzocimab & Anti-human platelet glycoprotein VI & Acute ischemic stroke & Phase I/II [NCT03803007] \\
\hline Naptumomabestafenatox & $\begin{array}{l}\text { Anti-5T4 antibody fused with a } \\
\text { staphylococcal superantigen }\end{array}$ & $\begin{array}{l}\text { Nonsmall cell lung } \\
\text { carcinoma }\end{array}$ & Phase I [NCT00056537] \\
\hline Onartuzumab & $\begin{array}{l}\text { Anti-Met } \\
\text { humanized Fab }\end{array}$ & Solid tumors & Phase III [NCT02488330] \\
\hline
\end{tabular}

visualization and mapping of biodistribution of programed death ligand 1 (PD-L1). ${ }^{84}$ In another interesting design, two Fabs were linked by PEG to obtain Fab-PEG-Fab, which was used as an anti-VEGF agent and displayed antiangiogenic properties comparable to or better than bevacizumab (a monoclonal IgG1 antibody that targets VEGF), thus showing a great potential in therapeutic indications. ${ }^{85}$

\section{Conclusions}

Among seven marketed Fab fragment drugs, only ranibizumab and certolizumab pegol are generated in E. coli as IBs. Low expression yields of Fab fragments in E. coli remains a bottleneck to the acquisition of commercially useful products. This article reviewed the production of Fab fragments in E. coli with several advantages over other platforms, such as low cost, well-understood cell biology, and easy manipulation. A series of optimizations at the molecular level have been attempted to enhance the production of Fab, including co-expression of chaperones to obtain correctly folded protein, optimization of secretion signal sequences, modification of host bacteria with gene deletion, or improving the culture conditions. Although an individual strategy may not be applicable to every protein production, each one is worth pursuing due to the possibility of greatly improved yield.

In addition, new antibody-enzyme fusion proteins and bifunctional antibodies may point to a promising direction to optimize the $E$. coli expression system. ${ }^{86}$ For example, Ritthisan et al reported efficient cytoplasmic soluble expression of a Fab fused with E. coli alkaline phosphatase (AP), Nterminal Ser-Lys-Ile-Lys (SKIK) tag and LZ, which proved to enhance the association of the light chain and the heavy chain of Fab. ${ }^{87}$ The SKIK-Fab-LZ-AP fusion was well expressed remaining the ability of antigen binding and AP activity. Kang et al demonstrated that removal of cysteine residues responsible for an interchain disulfide bond in a Fab molecule optimizes the periplasmic expression of a Fab- effector fusion protein in E. coli. ${ }^{88}$ Du et al generated bifunctional antibodies by grafting full-length proteins into constant region loops of a Fab, which showed that the fusion proteins retained antigen-binding activity of the parent antibody with an additional activity associated with the protein insert. ${ }^{89}$ At the same time, other production methods, such as yeast, transgenic plant, and cell-free expression systems, provide new alternatives to facilitate generation of Fab antibodies.

In conclusion, antibody drug diversification is expected to expand the range of innovative antibody-based therapeutics, including bispecific antibodies, antibody conjugates, and nanobodies. With the deeper understanding of the renaturation process, soluble protein expression, as well as the further development of genetic engineering, it is conceivable to produce antibody fragments with high yields and low costs. As one of the first small-molecule antibodies studied, Fab fragments are expected to play an increasingly important role in diagnosis and treatment of diseases.

\section{Funding}

This work was supported by the National Natural Science Foundation of China (Grant No. 32070722), the National Science and Technology Major Project (Grant No. 2019ZX09201001-003-008), and Shanghai Jiao Tong University Medicine Engineering Joint Funding (Grant No. YG2019ZDA04 and YG2019QNA50).

Conflict of Interest

The authors declared no conflict of interest.

\section{References}

1 Kaplon H, Reichert JM. Antibodies to watch in 2019. MAbs 2019; 11(02):219-238

2 Alibakhshi A, Abarghooi Kahaki F, Ahangarzadeh S, et al. Targeted cancer therapy through antibody fragments-decorated nanomedicines. J Control Release 2017;268:323-334 
3 Walsh G. Biopharmaceutical benchmarks 2018. Nat Biotechnol 2018;36(12):1136-1145

$4 \mathrm{Ma} \mathrm{H}, \mathrm{O}$ 'Kennedy R. Recombinant antibody fragment production. Methods 2017;116:23-33

5 Rader C. Overview on concepts and applications of Fab antibody fragments. Curr Protoc Protein Sci 2009; Chapter 6:Unit 6.9

6 Bever CS, Dong JX, Vasylieva N, et al. VHH antibodies: emerging reagents for the analysis of environmental chemicals. Anal Bioanal Chem 2016;408(22):5985-6002

7 de Aguiar RB, da Silva TA, Costa BA, et al. Generation and functional characterization of a single-chain variable fragment (scFv) of the anti-FGF2 3F12E7 monoclonal antibody. Sci Rep 2021;11(01):1432

8 Koerber JT, Hornsby MJ, Wells JA. An improved single-chain Fab platform for efficient display and recombinant expression. J Mol Biol 2015;427(02):576-586

9 Kirley TL, Greis KD, Norman AB. Selective disulfide reduction for labeling and enhancement of Fab antibody fragments. Biochem Biophys Res Commun 2016;480(04):752-757

10 An Y, Zhang Y, Mueller HM, Shameem M, Chen X. A new tool for monoclonal antibody analysis: application of IdeS proteolysis in IgG domain-specific characterization. MAbs 2014;6(04):879-893

11 Venturi M, Seifert C, Hunte C. High level production of functional antibody Fab fragments in an oxidizing bacterial cytoplasm. J Mol Biol 2002;315(01):1-8

12 Spadiut O, Capone S, Krainer F, Glieder A, Herwig C. Microbials for the production of monoclonal antibodies and antibody fragments. Trends Biotechnol 2014;32(01):54-60

13 Lebozec K, Jandrot-Perrus M, Avenard G, Favre-Bulle O, Billiald P. Quality and cost assessment of a recombinant antibody fragment produced from mammalian, yeast and prokaryotic host cells: a case study prior to pharmaceutical development. N Biotechnol 2018;44:31-40

14 Backovic M, Johansson DX, Klupp BG, Mettenleiter TC, Persson MA, Rey FA. Efficient method for production of high yields of Fab fragments in Drosophila S2 cells. Protein Eng Des Sel 2010;23(04): 169-174

15 Vazquez-Lombardi R, Nevoltris D, Luthra A, Schofield P, Zimmermann C, Christ D. Transient expression of human antibodies in mammalian cells. Nat Protoc 2018;13(01):99-117

16 Gaciarz A, Veijola J, Uchida Y, et al. Systematic screening of soluble expression of antibody fragments in the cytoplasm of E. coli. Microb Cell Fact 2016;15(01):22

17 Kwong KY, Rader C. E. coli expression and purification of fab antibody fragments. Curr Protoc Protein Sci 2009;Chapter 6:Unit 6.10

18 Stewart EJ, Aslund F, Beckwith J. Disulfide bond formation in the Escherichia coli cytoplasm: an in vivo role reversal for the thioredoxins. EMBO J 1998;17(19):5543-5550

19 Derman AI, Prinz WA, Belin D, Beckwith J. Mutations that allow disulfide bond formation in the cytoplasm of Escherichia coli. Science 1993;262(5140):1744-1747

20 Graumann K, Premstaller A. Manufacturing of recombinant therapeutic proteins in microbial systems. Biotechnol J 2006;1(02): 164-186

21 Burgess RR. Refolding solubilized inclusion body proteins. Methods Enzymol 2009;463:259-282

22 González-Montalban N, García-Fruitós E, Ventura S, et al. Comparative analysis of $\mathrm{E}$. coli inclusion bodies and thermal protein aggregates. Microb Cell Fact 2006;5(01):16

23 Friedrich L, Stangl S, Hahne H, et al. Bacterial production and functional characterization of the Fab fragment of the murine IgG1/lambda monoclonal antibody cmHsp70.1, a reagent for tumour diagnostics. Protein Eng Des Sel 2010;23(04):161-168

24 Rezaie F, Davami F, Mansouri K, et al. Cytosolic expression of functional Fab fragments in Escherichia coli using a novel combination of dual SUMO expression cassette and EnBase ${ }^{\circledR}$ cultivation mode. J Appl Microbiol 2017;123(01):134-144
25 Ojima-Kato T, Fukui K, Yamamoto H, et al. 'Zipbody' leucine zipper-fused Fab in E. coli in vitro and in vivo expression systems. Protein Eng Des Sel 2016;29(04):149-157

26 Singh SM, Panda AK. Solubilization and refolding of bacterial inclusion body proteins. J Biosci Bioeng 2005;99(04):303-310

27 Vallejo LF, Rinas U. Strategies for the recovery of active proteins through refolding of bacterial inclusion body proteins. Microb Cell Fact 2004;3(01):11

28 Rinas U, Hoffmann F, Betiku E, Estapé D, Marten S. Inclusion body anatomy and functioning of chaperone-mediated in vivo inclusion body disassembly during high-level recombinant protein production in Escherichia coli. J Biotechnol 2007;127(02): 244-257

29 Singh A, Upadhyay V, Upadhyay AK, Singh SM, Panda AK. Protein recovery from inclusion bodies of Escherichia coli using mild solubilization process. Microb Cell Fact 2015;14(01):41

30 Misawa S, Kumagai I. Refolding of therapeutic proteins produced in Escherichia coli as inclusion bodies. Biopolymers 1999;51(04): 297-307

31 Arora D, Khanna N. Method for increasing the yield of properly folded recombinant human gamma interferon from inclusion bodies. J Biotechnol 1996;52(02):127-133

32 Buchner J, Rudolph R. Renaturation, purification and characterization of recombinant Fab-fragments produced in Escherichia coli. Biotechnology (N Y) 1991;9(02):157-162

33 Luo M, Zhao M, Cagliero C, et al. A general platform for efficient extracellular expression and purification of Fab from Escherichia coli. Appl Microbiol Biotechnol 2019;103(08):3341-3353

34 Ellis M, Patel P, Edon M, Ramage W, Dickinson R, Humphreys DP. Development of a high yielding E. coli periplasmic expression system for the production of humanized Fab' fragments. Biotechnol Prog 2017;33(01):212-220

35 Gupta SK, Shukla P. Microbial platform technology for recombinant antibody fragment production: a review. Crit Rev Microbiol 2017;43(01):31-42

36 Corisdeo S, Wang B. Functional expression and display of an antibody Fab fragment in Escherichia coli: study of vector designs and culture conditions. Protein Expr Purif 2004;34(02):270-279

37 Lin B, Renshaw MW, Autote K, et al. A step-wise approach significantly enhances protein yield of a rationally-designed agonist antibody fragment in E. coli. Protein Expr Purif 2008;59(01): $55-63$

38 Gupta SK, Shukla P. Advanced technologies for improved expression of recombinant proteins in bacteria: perspectives and applications. Crit Rev Biotechnol 2016;36(06):1089-1098

39 Thie H, Schirrmann T, Paschke M, Dübel S, Hust M. SRP and Sec pathway leader peptides for antibody phage display and antibody fragment production in E. coli. N Biotechnol 2008;25(01): 49-54

40 Nagano R, Masuda K. Establishment of a signal peptide with crossspecies compatibility for functional antibody expression in both Escherichia coli and Chinese hamster ovary cells. Biochem Biophys Res Commun 2014;447(04):655-659

41 Burioni R, Plaisant P, Bugli F, Delli Carri V, Clementi M, Fadda G. A vector for the expression of recombinant monoclonal Fab fragments in bacteria. J Immunol Methods 1998;217(1-2):195-199

42 Levy R, Weiss R, Chen G, Iverson BL, Georgiou G. Production of correctly folded Fab antibody fragment in the cytoplasm of Escherichia coli trxB gor mutants via the coexpression of molecular chaperones. Protein Expr Purif 2001;23(02):338-347

43 Kumar S, Kalsi J, Ravirajan CT, et al. Molecular cloning and expression of the Fabs of human autoantibodies in Escherichia coli. Determination of the heavy or light chain contribution to the anti-DNA/-cardiolipin activity of the Fab. J Biol Chem 2000;275 (45):35129-35136

44 Elena C, Ravasi P, Castelli ME, Peirú S, Menzella HG. Expression of codon optimized genes in microbial systems: current industrial applications and perspectives. Front Microbiol 2014;5:21 
45 Nissley DA, Sharma AK, Ahmed N, et al. Accurate prediction of cellular co-translational folding indicates proteins can switch from post- to co-translational folding. Nat Commun 2016; 7:10341

46 Goodman DB, Church GM, Kosuri S. Causes and effects of Nterminal codon bias in bacterial genes. Science 2013;342 (6157):475-479

47 Zalucki YM, Jennings MP. Experimental confirmation of a key role for non-optimal codons in protein export. Biochem Biophys Res Commun 2007;355(01):143-148

48 Pechmann S, Chartron JW, Frydman J. Local slowdown of translation by nonoptimal codons promotes nascent-chain recognition by SRP in vivo. Nat Struct Mol Biol 2014;21(12):1100-1105

49 Kulmala A, Huovinen T, Lamminmäki U. Improvement of Fab expression by screening combinatorial synonymous signal sequence libraries. Microb Cell Fact 2019;18(01):157

50 Khow O, Suntrarachun S. Strategies for production of active eukaryotic proteins in bacterial expression system. Asian Pac J Trop Biomed 2012;2(02):159-162

51 Chung KT, Lee TH, Kang GS. Isolation of proteins that speifically interact with the ATPase domain of mammalian ER chaperone, BiP. Biotechnol Bioprocess Eng 2003;8(03):192-198

52 Ow DS, Lim DY, Nissom PM, Camattari A, Wong VV. Co-expression of Skp and FkpA chaperones improves cell viability and alters the global expression of stress response genes during scFvD1.3 production. Microb Cell Fact 2010;9:22

53 Webb HM, Ruddock LW, Marchant RJ, Jonas K, Klappa P. Interaction of the periplasmic peptidylprolyl cis-trans isomerase SurA with model peptides. The N-terminal region of SurA id essential and sufficient for peptide binding. J Biol Chem 2001;276(49): 45622-45627

54 Rodriguez-Carmona E, Cano-Garrido O, Dragosits M, et al. Recombinant Fab expression and secretion in Escherichia coli continuous culture at medium cell densities: Influence of temperature. Process Biochem 2012;47(03):446-452

55 Yang Q Xu J, Li M, Lei X, An L. High-level expression of a soluble snake venom enzyme, gloshedobin, in E. coli in the presence of metal ions. Biotechnol Lett 2003;25(08):607-610

56 Kim SJ, Ha GS, Lee G, et al. Enhanced expression of soluble antibody fragments by low-temperature and overdosing with a nitrogen source. Enzyme Microb Technol 2018;115:9-15

57 An F, Chen YC, Fan LY, Han HX. Fed-batch fermentation of Escherichia coli that express fab fragment of anti-HBsAg [in Chinese]. Sheng Wu Gong Cheng Xue Bao 2003;19(01):87-91

58 O'Brien PM, Maxwell G, Campo MS. Bacterial expression and purification of recombinant bovine Fab fragments. Protein Expr Purif 2002;24(01):43-50

59 Bäcklund E, Reeks D, Markland K, Weir N, Bowering L, Larsson G. Fedbatch design for periplasmic product retention in Escherichia coli. J Biotechnol 2008;135(04):358-365

60 Ukkonen K, Veijola J, Vasala A, Neubauer P. Effect of culture medium, host strain and oxygen transfer on recombinant Fab antibody fragment yield and leakage to medium in shaken E. coli cultures. Microb Cell Fact 2013;12:73

61 Schofield DM, Templar A, Newton J, Nesbeth DN. Promoter engineering to optimize recombinant periplasmic Fab' fragment production in Escherichia coli. Biotechnol Prog 2016;32(04): 840-847

62 Chodorge M, Züger S, Stirnimann C, et al. A series of Fas receptor agonist antibodies that demonstrate an inverse correlation between affinity and potency. Cell Death Differ 2012;19(07): 1187-1195

63 Holzer W, Petersen F, Strittmatter W, Matzku S, von Hoegen I. A fusion protein of IL- 8 and a Fab antibody fragments binds to IL- 8 receptors and induces neutrophil activation. Cytokine 1996;8 (03):214-221

64 Nelke J, Medler J, Weisenberger D, Beilhack A, Wajant H. CD40and CD95-specific antibody single chain-Baff fusion proteins display BaffR-, TACI- and BCMA-restricted agonism. MAbs 2020;12(01):1807721

65 Bauss F, Lechmann M, Krippendorff B-F, et al. Characterization of a re-engineered, mesothelin-targeted Pseudomonas exotoxin fusion protein for lung cancer therapy. Mol Oncol 2016;10(08): 1317-1329

66 Nascimento A, Mullerpatan A, Azevedo AM, Karande P, Cramer S. Development of phage biopanning strategies to identify affinity peptide ligands for kappa light chain Fab fragments. Biotechnol Prog 2019;35(06):e2884

67 Zhao Y, Gutshall L, Jiang $\mathrm{H}$, et al. Two routes for production and purification of Fab fragments in biopharmaceutical discovery research: Papain digestion of $\mathrm{mAb}$ and transient expression in mammalian cells. Protein Expr Purif 2009;67(02):182-189

68 Malpiedi LP, Díaz CA, Nerli BB, et al. Single-chain antibody fragments: purification methodologies. Process Biochem 2013;48 (08):1242-1251

69 McMahon MJ, O'Kennedy R. Polyreactivity as an acquired artefact, rather than a physiologic property, of antibodies: evidence that monoreactive antibodies may gain the ability to bind to multiple antigens after exposure to low pH. J Immunol Methods 2000;241 $(1-2): 1-10$

70 Alves NJ, Stimple SD, Handlogten MW, Ashley JD, Kiziltepe T, Bilgicer B. Small-molecule-based affinity chromatography method for antibody purification via nucleotide binding site targeting. Anal Chem 2012;84(18):7721-7728

71 Spooner J, Keen J, Nayyar K, et al. Evaluation of strategies to control Fab light chain dimer during mammalian expression and purification: a universal one-step process for purification of correctly assembled Fab. Biotechnol Bioeng 2015;112(07):1472-1477

72 Jalalirad R. Efficient chromatographic processes for elevated purification of antibody fragment (Fab D1.3) from crude escherichia coli culture. Biotechnology 2013;12(02):74-80

73 Rouby G, Tran NT, Leblanc Y, Taverna M, Bihoreau N. Investigation of monoclonal antibody dimers in a final formulated drug by separation techniques coupled to native mass spectrometry. MAbs 2020;12(01):e1781743

74 Nasiri H, Valedkarimi Z, Aghebati-Maleki L, et al. Production and purification of polyclonal antibody against $F\left(a^{\prime}\right) 2$ fragment of human immunoglobulin G. Vet Res Forum 2017;8(04):307-312

75 Smith AG, Kaiser PK. Therapeutic monoclonal antibodies and fragments: Ranibizumab. Dev Ophthalmol 2016;55:246-251

76 Nakamura H, Oda-Ueda N, Ueda T, Ohkuri T. A novel engineered interchain disulfide bond in the constant region enhances the thermostability of adalimumab Fab. Biochem Biophys Res Commun 2018;495(01):7-11

77 Campanati A, Benfaremo D, Luchetti MM, Ganzetti G, Gabrielli A, Offidani A. Certolizumab pegol for the treatment of psoriasis. Expert Opin Biol Ther 2017;17(03):387-394

78 Ruiz Garcia V, Burls A, Cabello JB, Vela Casasempere P, Bort-Marti S, Bernal JA. Certolizumab pegol (CDP870) for rheumatoid arthritis in adults. Cochrane Database Syst Rev 2017;9(09):CD007649

79 Goel N, Stephens S. Certolizumab pegol. MAbs 2010;2(02): 137-147

80 Kanje S, von Witting E, Chiang SC, Bryceson YT, Hober S. Sitespecific photolabeling of the IgG Fab fragment using a small protein G derived domain. Bioconjug Chem 2016;27(09): 2095-2102

81 Zhou Z, Zhang J, Zhang Y, Ma G, Su Z. Specific conjugation of the hinge region for homogeneous preparation of antibody fragmentdrug conjugate: a case study for doxorubicin-PEG-anti-CD20 Fab' synthesis. Bioconjug Chem 2016;27(01):238-246

82 Kornberger P, Skerra A. Sortase-catalyzed in vitro functionalization of a HER2-specific recombinant Fab for tumor targeting of the plant cytotoxin gelonin. MAbs 2014;6(02):354-366

83 Huang R, Sheng Y, Wei D, Yu J, Chen H, Jiang B. Bis(vinylsulfonyl) piperazines as efficient linkers for highly homogeneous antibodydrug conjugates. Eur J Med Chem 2020;190:112080 
84 Wissler HL, Ehlerding EB, Lyu Z, et al. Site-specific immunoPET tracer to image PD-L1. Mol Pharm 2019;16(05): 2028-2036

85 Khalili H, Godwin A, Choi JW, Lever R, Khaw PT, Brocchini S. FabPEG-Fab as a potential antibody mimetic. Bioconjug Chem 2013; 24(11):1870-1882

86 Mori A, Ojima-Kato T, Kojima T, Nakano H. Zipbodyzyme: development of new antibody-enzyme fusion proteins. J Biosci Bioeng 2018;125(06):637-643

87 Ritthisan P, Ojima-Kato T, Damnjanović J, Kojima T, Nakano H. SKIK-zipbody-alkaline phosphatase, a novel antibody fusion protein expressed in Escherichia coli cytoplasm. J Biosci Bioeng 2018; 126(06):705-709

88 Kang HJ, Kim HJ, Jung MS, Han JK, Cha SH. Optimal expression of a Fab-effector fusion protein in Escherichia coli by removing the cysteine residues responsible for an interchain disulfide bond of a Fab molecule. Immunol Lett 2017;184:34-42
89 Du J, Cao Y, Liu Y, et al. Engineering bifunctional antibodies with constant region fusion architectures. J Am Chem Soc 2017;139 (51):18607-18615

90 Rodriguez C, Nam DH, Kruchowy E, Ge X. Efficient antibody assembly in E. coli periplasm by disulfide bond folding factor co-expression and culture optimization. Appl Biochem Biotechnol 2017;183(02):520-529

91 Fink M, Vazulka S, Egger E, et al. Microbioreactor cultivations of Fab-producing Escherichia coli reveal genome-integrated systems as suitable for prospective studies on direct Fab expression effects. Biotechnol J 2019;14(11):e1800637

92 Dariushnejad H, Farajnia S, Zarghami N, et al. Effect of DnaK/DnaJ/ GrpE and DsbC chaperons on periplasmic expression of Fab antibody by E. coli SEC pathway. Int J Pept Res 2019;25(01):67-74

93 Rodríguez-Martínez LM, Marquez-Ipiña AR, López-Pacheco F, et al. Antibody derived peptides for detection of Ebola virus glycoprotein. PLoS One 2015;10(10):e0135859 